\title{
AN ANALYSIS OF PUMP POWER CALCULATION OF CONVERTED BANDUNG TRIGA REACTOR WITH PIPE ROUTING THROUGH DELAY TANK
}

\author{
V. Indriati Sri Wardhani ${ }^{1)^{*}}$ dan Budi Santoso ${ }^{2)}$ \\ ${ }^{1)}$ Pusat Sains dan Teknologi Nuklir Terapan- Batan- Jl. Tamansari- Bandung \\ ${ }^{2)}$ Pusat Rekayasa Fasilitas Nuklir-Kawasan Puspiptek- Serpong \\ *E-mail: vero@batan.go.id \\ Diterima editor: 17 September 2018 \\ Direvisi editor: 17 Oktober 2018 \\ Disetujui untuk publikasi: 18 Oktober 2018
}

\begin{abstract}
AN ANALYSIS OF PUMP POWER CALCULATION OF CONVERTED BANDUNG TRIGA REACTOR WITH PIPE ROUTING THROUGH DELAY TANK. The Bandung TRIGA 2000 Reactor has been widely used for conducting training, researches and isotop production since 1965. This reactor have to be decommissioned due no further fuelproduced by original vendor. Therefore, conversion of cylinder fuel into plate is needed. PT INUKI has been able to produce its own plate type fuel so that by changing the reactor core which was originally cylindrical into a square shape or converting the fuel element from cylindrical to plate type operation of the Bandung TRIGA 2000 reactor can be maintained for a long time. On this conversion, the reactor's cooling system will change, which initially by natural convection to forced convection, while the direction of the cooling flow changes as well, which initially from bottom to top becomes from top to bottom. If the directional cooling flow of the plate TRIGA reactor system is made from top to bottom, without changing of piping, the result is a high exposure of Nitrogen-16 radiation on the surface of the reactor tank, therefore a delay tank is needed. By the new pipe routing system, it is necessary to reanalyze on determining the pump power requirements. The pump should be able to supply this energy. In other words, the total head produced by the pump must be equal to the total head required by the system. If the total system head data and coolant flow rate, and considering the efficiency of the pump and the motor drive pump have been analysed, so the pump power requirements can be calculated. The calculation result shows that the amount of pump power required to drain the cooling fluid in the primary system is $35 \mathrm{~kW}$ or $47 \mathrm{HP}$.
\end{abstract}

Keywords: conversion, cooling, plate type, pipe routing, pumps

ABSTRAK

ANALISIS PERHITUNGAN DAYA POMPA KONVERSI REAKTOR TRIGA BANDUNG DENGAN ROUTING PERPIPAAN MELALUI TANKI TUNDA. Reaktor TRIGA 2000 Bandung merupakan fasilitas yang sudah banyak digunakan untuk training, penelitian dan produksi isotop sejak tahun 1965. Reaktor ini terancam padam karena tidak ada lagi bahan bakar yang diproduksi oleh pemasok awalnya. Oleh karena itu langkah konversi reaktor TRIGA 2000 berbahan bakar silinder ke bahan bakar pelat harus dilakukan. PT INUKI telah mampu memproduksi bahan bakar tipe pelat sendiri, sehingga dengan mengubah teras reaktor yang semula berbentuk silinder menjadi bentuk persegi atau melakukan konversi reaktor dari bahan bakar tipe silinder ke tipe pelat operasi reaktor TRIGA 2000 Bandung dapat dipertahankan untuk waktu yang lama. Pada konversi ini, sistem pendinginan reaktor akan berubah, yang semula secara konveksi alamiah, menjadi konveksi paksa, sementara arah aliran pendingin berubah juga, yang semula dari bawah ke atas menjadi dari atas ke bawah. Jika pada sistem reaktor TRIGA pelat arah alirannya dibuat dari atas ke bawah, tanpa adanya perubahan perpipaan akan berakibat paparan radiasi Nitrogen-16 di permukaan tangki reaktor menjadi tinggi, oleh karena itu diperlukan tanki tunda. Pada keadaan sistem perpipaan yang baru ini perlu dilakukan analisis kembali untuk menentukan kebutuhan daya pompa. Pompa harus mampu memasok energi yang diperlukan ini. Dengan kata lain, head total yang dihasilkan oleh pompa harus sama dengan head total yang diperlukan oleh sistem. Jika data total head sistem dan laju aliran pendingin, serta mempertimbangkan effisiensi pompa dan motor penggerak pompa telah diperoleh, maka kebutuhan daya pompa dapat dihitung. Hasil perhitungan menunjukkan bahwa daya pompa yang diperlukan untuk mengalirkan sistem pendingin primer adalah sebesar $35 \mathrm{~kW}$ atau $47 \mathrm{Hp}$.

Kata kunci: konversi, pendingin, tipe pelat, routing perpipaan, pompa. 


\section{INTRODUCTION}

PT INUKI has been able to produce its own plate type $\mathrm{U}_{3} \mathrm{Si}_{2}-\mathrm{Al}$ fuel and it has been used in the RSG-GAS reactor. On this capability, a conversion of the Bandung TRIGA 2000 reactor is planned to be a TRIGA reactor with fuel in the form of a plate so that it does not depend on fuel supply from other countries. The conversion is carried out by changing the reactor core which was originally cylindrical into a plate shapes, therefore there are several reactor systems should be modified, by means of the core system and its construction as well as the primary cooling system [1]. The composition of the reactor core is a $5 \times 5$ matrix configuration, it consists of 16 positions for the fuel element, 4 positions for control elements and 5 irradiation positions. Whereas the change in the fuel elements resulted in the primary cooling system also changing from the natural convection cooling system to forced convection, the direction of flow from the the upper towards the bottom of the reactor core. Changes in the flow direction of the cooling system will affect the rate of radioactive exposure of Nitrogen-16 in the core formed by the reaction of neutrons with water and carried by the cooling fluid to the surface of the reactor tank. Therefore, it is necessary to design a delay tank to delay the flow of Nitrogen-16 out of the reactor tank until exposure to Nitrogen-16 radiation coming out from the reactor tank, the delay tank is placed in the primary system $[2,3]$.

The equipment of primary cooling pipe system consists of delay tank, pumps, heat exchanger and piping that connects equipment to each other. The piping line starts from the tank output nozzle towards the primary pump nozzle, then from the primary pump nozzle to the nozzle entering the heat exchanger and from the heat exchanger output nozzle in addition to the reactor core. Cooling fluid flows from top to bottom of the reactor core is forcibly sucked with an available pump. Changing of the cylindrical fuel type to the plate type will also cause the cooling system to change, a large system change occurs in the primary cooling system, starting from the tank output nozzle (under the reactor core) to the primary pump nozzle, then from the primary pump nozzle to the inserting nozzle heat and from the heat exchanger output nozzles enter above the reactor core, this also results in changes in the piping system [4,5]. Whereas for the secondary cooling system can use the existing secondary cooling system of TRIGA 2000 Bandung reactor but it is necessary to re-analyze the cooling process. With the state of the new piping system, it is necessary to recalculate the pump power requirements that must be provided by the existing pump [6].

\section{THEORY}

In general, the channel used to move fluid from one place to another has a circular section such as a water pipe, a hydraulic hose and other channels designed to withstand a very large pressure difference when crossing the walls without causing changes in shape. It is also assumed that the pipe fully charged by the transferred fluid and the main driving force is the pressure gradient along the pipe. The fluid which is flowing in the pipe has a pressure drop due to frictional force while the frictional force is caused by resistance to flow. The main factors that influence resistance to fluid flow are the velocity of the fluid through the pipe and the viscosity of the fluid. The flow profile of the fluid passing through the pipe will be affected by the fluid momentum which makes the fluid move inside the pipe, the viscous force that holds the flow in the pipe wall and the internal friction of the fluid itself. Besides that, it is also affected by pipe turns, elbows, mitters, tees, reducers, cross, valves and so forth. The various forms and models are very helpful to the design of the piping system layout and to have different stress characteristics as a result of the received load. The accumulation of the weight of the pipe itself and the pressure of the fluid flowing in it will cause the stress on the pipe which is referred as static load. However, the effects of this type of loading can be minimized by choosing the appropriate type of support [7,8].

A pump is a machine that adds energy to a liquid in order to increase the pressure or move the liquid through a pipe. Broadly speaking, the pump can be divided into two types, namely: centrifugal or rotor dynamic pumps and positive displacement pumps. Centrifugal pumps are a common type of pump and are widely used due to the low cost, simple construction, reliable 
operation, large capacity, good efficiency, besides they can be used for high temperatures. Centrifugal pumps move fluid by utilizing the centrifugal force produced by the impeller rotation and convert the velocity energy into pressure energy. The faster the pump rotation, the higher the pressure or head will be produced. The total head produced by the pump should be the same as the total head needed by the system. The total head is calssified into three types, namely: static head which refers to the difference in the height of the liquid surface (static head), surface pressure (liquid pressure) and the friction head which is the amount of loss that occurs in the piping system. The magnitude of these losses varies depending on the length of the pipe, the diameter and roughness of the inside of the pipe, the size of the pump capacity, the type of valve and in the pipe which is often used is the Darcy-Wesbach formula as follows $[9,10]$ :

$$
h_{f}=f \frac{L}{D} \frac{V^{2}}{2 g}
$$

$h_{f}=$ friction head (ft or $\mathrm{m}$ )

$f=$ friction factor

$\mathrm{L}=$ length of pipe ( $\mathrm{ft}$ or $\mathrm{m}$ )

$\mathrm{D}$ = inside diameter of pipe (ft or $\mathrm{m}$ )

$\mathrm{V}=$ flow velocity $(\mathrm{ft} / \mathrm{s}$ or $\mathrm{m} / \mathrm{sec})$

$\mathrm{g}=$ acceleration of gravity $\left(32,2 \mathrm{ft} / \mathrm{s}^{2}\right.$ or $\left.9.81 \mathrm{~m} / \mathrm{s}^{2}\right)$

Head losses for valves and elbows :

$$
h_{f}=K \frac{V^{2}}{2 g}
$$

Where :

$\mathrm{K}=$ coeffisien of valves or elbows [9]

$\mathrm{V}=$ fluid velocity $(\mathrm{ft} / \mathrm{s}$ or $\mathrm{m} / \mathrm{s})$

$\mathrm{g}=$ gravity acceleration $\left(32,2 \mathrm{ft} / \mathrm{s}^{2}\right.$ or $\left.9.81 \mathrm{~m} / \mathrm{s}^{2}\right)$

A relationship exists between Reynolds number, friction factor, and relative roughness. Reynolds number is based on diameter of pipe, fluid properties of viscosity, density, and velocity. For Reynolds number smaller than 2000, the pipe roughness does not apply and the friction factor can be calculated as $\mathrm{f}=64 / \mathrm{Nr}$. Reynolds number in the range of 2000-4000 are in critical zone and the values of "f" are indeterminate. For Reynolds number above 4000, in both the transition and complete turbulence zones, Reynolds number and relative roughness must be used to determine the friction factor.

$$
\mathrm{Re}=\mathrm{VD} / \mathrm{k}
$$

where:

$$
\begin{aligned}
& \mathrm{Re}=\text { Reynolds Number } \\
& \mathrm{V}=\text { fluid velocity }(\mathrm{ft} / \mathrm{sec} \text { or } \mathrm{m} / \mathrm{sec}) \\
& \mathrm{D}=\text { inside diameter of pipe }(\mathrm{ft} \text { or } \mathrm{m}) \\
& \mathrm{k}=\text { Kinematic viscosity }\left(\mathrm{ft}^{2} / \mathrm{s} \text { or } \mathrm{m}^{2} / \mathrm{s}\right), \text { where: } \\
& \mathrm{k}=\mathrm{a} /(\mathrm{w} / \mathrm{g}) \\
& \mathrm{a}=\text { absolute viscosity }\left(\mathrm{lb} . \mathrm{s} / \mathrm{ft}^{2} \text { or } \mathrm{kg} . \mathrm{s} / \mathrm{m}^{2}\right) \\
& \mathrm{w}=\text { specific weights }\left(\mathrm{lb} / \mathrm{ft}^{\mathrm{H}} \text { or } \mathrm{kg} / \mathrm{m}^{3}\right) \\
& \mathrm{g}=\text { acceleration of gravity }\left(32.2 \mathrm{ft} / \mathrm{s}^{2} \text { or } 9.81 \mathrm{~m} / \mathrm{s}^{2}\right)
\end{aligned}
$$

The hydraulic power which is also known as absorbed power, represents the energy imparted on the fluid being pumped to increase its velocity and pressure. The hydraulic power may be calculated using the formula below :

Hydraulic Power ;

$$
\mathrm{P}_{\mathrm{h}}=(9.81) \times \text { Head }(\mathrm{m}) \mathrm{x} \text { flow rate }(\mathrm{kg} / \mathrm{sec}) \mathrm{x} \text { specific gravity / } 1000
$$


The shaft power is the power supplied by the motor to the pump shaft. Shaft power is the sum of the hydraulic power (discussed above) and power loss due to inefficiencies in power transmission from the shaft to the fluid. Shaft power is typically calculated as the hydraulic power of the pump divided by the pump efficiency as follows:

$$
\text { Shaft Power, } \mathrm{P}_{\mathrm{s}}=\mathrm{P}_{\mathrm{h}} / \eta_{\mathrm{p}}
$$

The motor power is the power consumed by the pump motor to turn the pump shaft. The motor power is the sum of the shaft power and power loss due to inefficiencies in converting electric energy into kinetic energy. Motor power may be calculated as the shaft power divided by the motor efficiency.

$$
\text { Motor Power, } \mathrm{P}_{\mathrm{m}}=\mathrm{P}_{\mathrm{s}} / \eta_{\mathrm{m}}
$$

\section{METHODOLOGY}

In addition to delaying the flow of Nitrogen-16 out of the reactor tank until exposure to Nitrogen-16 radiation coming out of the reactor tank has decreased, pipes routing by placing a delay tank on the primary cooling system should also consider the available area in the reactor hall. Cooling fluid in pipe routing of the primary system is a closed cycle. The cooling fluid flows from the nozzle at the bottom of the reactor tank, through a delay tank, entering the suction side of the pump. On the pump discharge side, the fluid flows through the heat exchanger, and it goes back to the reactor tank. Pipe routing from the reactor tank, through the delay tank, and entering the suction side of the pump is called as the pipe routing of the suction of pump. Pipe routing exits the pump, enters the heat exchanger, and returns to the reactor tank called as the pipe routing of the discharge of pump. Pipe routing of suction of pump and pipe routing of the discharge of pump are shown in the fig.2, fig.3, and fig.4.

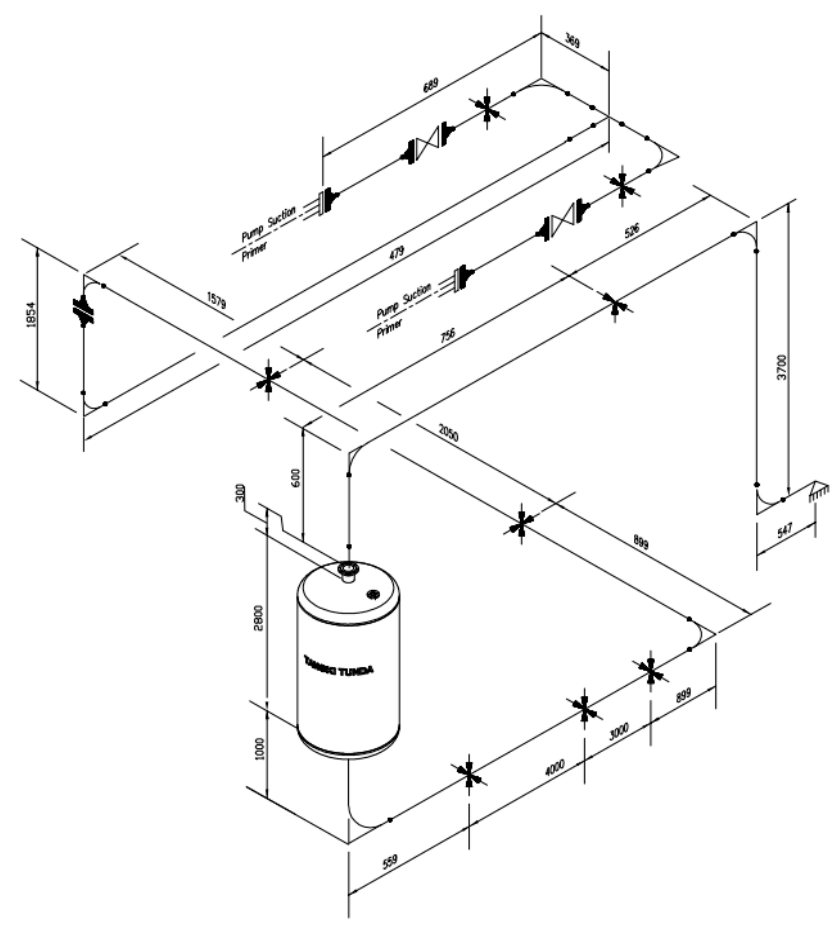

Figure 1. Pipe routing of the suction of pump 


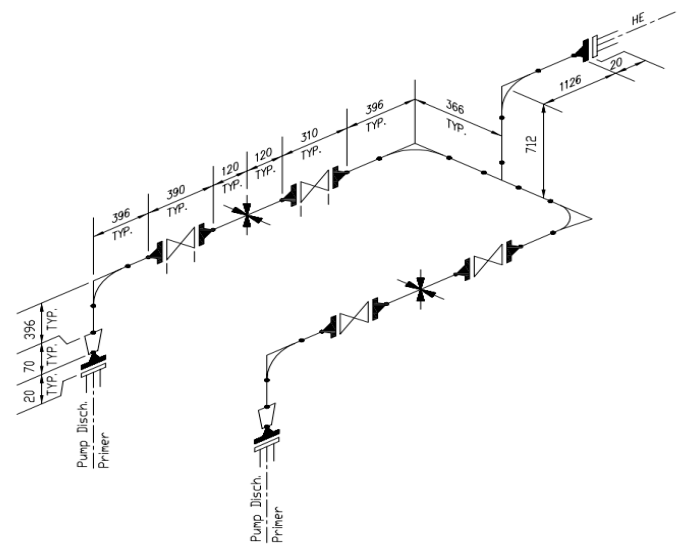

Figure 2. Pipe routing of the discharge of pump to HE

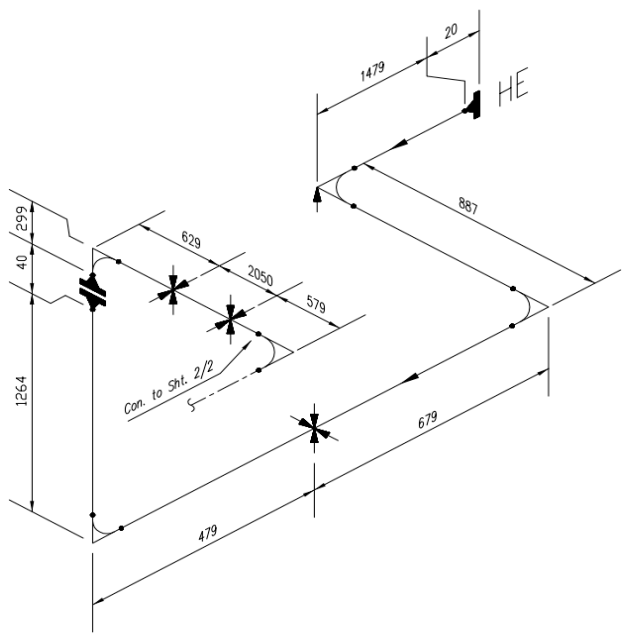

Figure 3. Pipe routing of HE to Reactor Tank

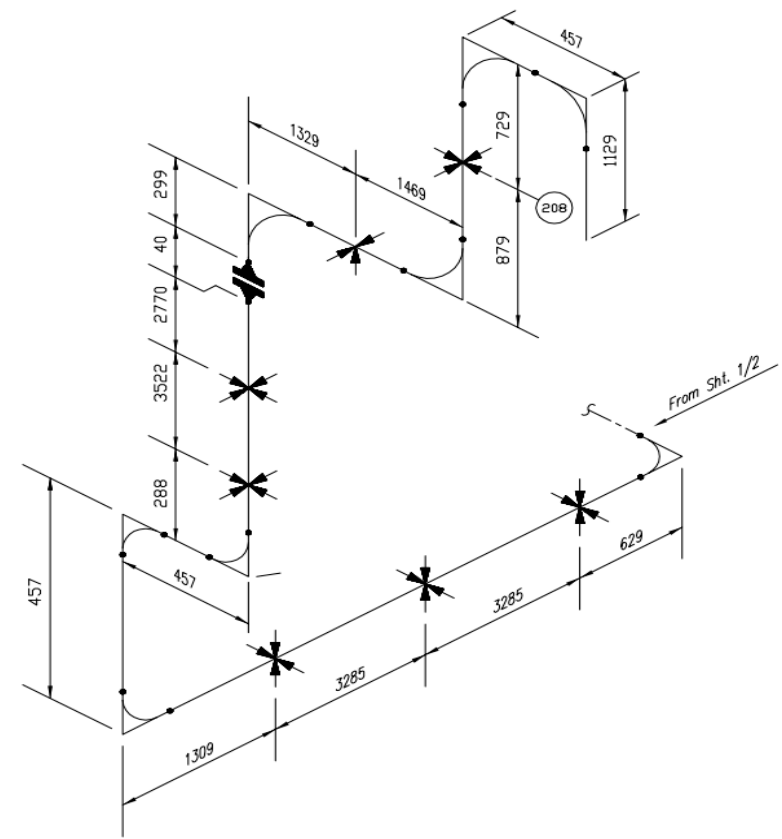

Figure 4. Pipe routing of HE to Reactor Tank (Continue) 
The energy required by the fluid flowing in the pipe routing of the suction of pump is called the suction head system. While the energy required to the fluid flowing in the pipe routing of discharge of pump is called a discharge head system. The total energy required by the pump to flows the fluid in a closed cycle is called the total head. As described above, the total head size can be determined from the suction and discharge side static heads, the surface pressure converted in units of feet or meters and the head due to friction when the cooling fluid flows through the piping system. By knowing the amount of the total head, and the cooling fluid flow rate, and assuming the values of the pump and motor efficiencies, then the power provided by the pump to flow the cooling fluid in the primary cooling system can be determined.

\section{RESULTS AND DISCUSSION}

The figures of the piping system above (fig.2, fig.3, and fig.4), show that the total length of the suction side pipe is $23.81 \mathrm{~m}$, while the total length of the discharge side pipe is $33.97 \mathrm{~m}$. Diameter of pipe is about 6 inch or $0.16828 \mathrm{~m}$. Taking into account the characteristics of the cooling fluid and the type of pipe material used, the losses due to elbows and valves, and assuming the efficiencies of the pump and motor, thus, the power provided by the pump in the primary system can be calculated using the formula stated in equation 1 until equation 6 . The characteristics of cooling fluid, pipe routing data, and as well as the calculation of pump power that should be provided in the primary cooling system, shown in table 1 and figure 5.

Table 1 . The primary pump calculation

\begin{tabular}{lcr}
\hline Parameters & UNIT & Values \\
\hline Type of cooling fluid & $\mathrm{kg} / \mathrm{s}$ & $70[2,3]$ \\
Flow rate & & 0.983 \\
Specific gravity & ${ }^{\circ} \mathrm{C}$ & 40 \\
Temperature & $\mathrm{kg} / \mathrm{m} 3$ & 983 \\
Density & $\mathrm{m} 3 / \mathrm{s}$ & 0.07121058 \\
Volume rate & $\mathrm{m} 2 / \mathrm{s}$ & 0.000000801 \\
Dynamic vscosity & & \\
& $\mathrm{m}$ & 0.16828 \\
Diameter of pipe & $\mathrm{m} 2$ & 0.022228433 \\
Cross section area of pipe & $\mathrm{m} / \mathrm{s}$ & 3.203580688 \\
Fluid velocity & & 673011.9105 \\
Reynolds number & & 0.00004572 \\
Pipe roughness & & 0.014614943 \\
Coefficient of friction & $\mathrm{m}$ & 23.81 \\
Pipe suction length & & 8.1 \\
Losses of elbows at suction side & & 0.2 \\
Losses of valves at suction side & & 0.2 \\
Losses of pipe entrance of delay tank & & 1.0 \\
Losses of pipe exit of delay tank & & 1.0 \\
Losses of pipe exit of reactor tank & $\mathrm{m}$ & 1.43 \\
Losses of delayed tank & $\mathrm{m}$ & 8.56 \\
Losses of pipe at suction side & $\mathrm{m}$ & 1.08559 \\
Suction head static & & \\
Total suction head & & 8.004099387 \\
Pump section pressure & & \\
\hline
\end{tabular}




\begin{tabular}{lrr}
\hline Parameters & UNIT & Values \\
\hline & Bar & 0.08 \\
Vapour pressure & $\mathrm{m}$ & 1 \\
Safety factor & Bar \\
Net Positive Suction Head & $\mathrm{m}$ & 9.055900613 \\
& & 33.97 \\
Pipe discharge length & & 14.4 \\
Losses of elbows at discharge side & & 0.4 \\
Losses of valves at discharge side & & 0.2 \\
Losses of pipe entrance of heat exchanger & & 1.0 \\
Losses of pipe exit of heat exchanger & $\mathrm{m}$ & 0.2 \\
Losses of pipe entrance of reactor tank & $\mathrm{m}$ & 2 \\
Losses of heat exchanger & $\mathrm{m}$ & 10.01726071 \\
Losses of pipe at discharge side & $\mathrm{m}$ & 20 \\
Losses at outlet & $\mathrm{m}$ & 32 \\
Total discharge head & & 32.01726071 \\
Total head & & 32.57316133 \\
Pump Efficiency & & 0.75 \\
Mechanical Efficiency & & 0.85 \\
\hline Power of primary pump & & 47 \\
\hline
\end{tabular}

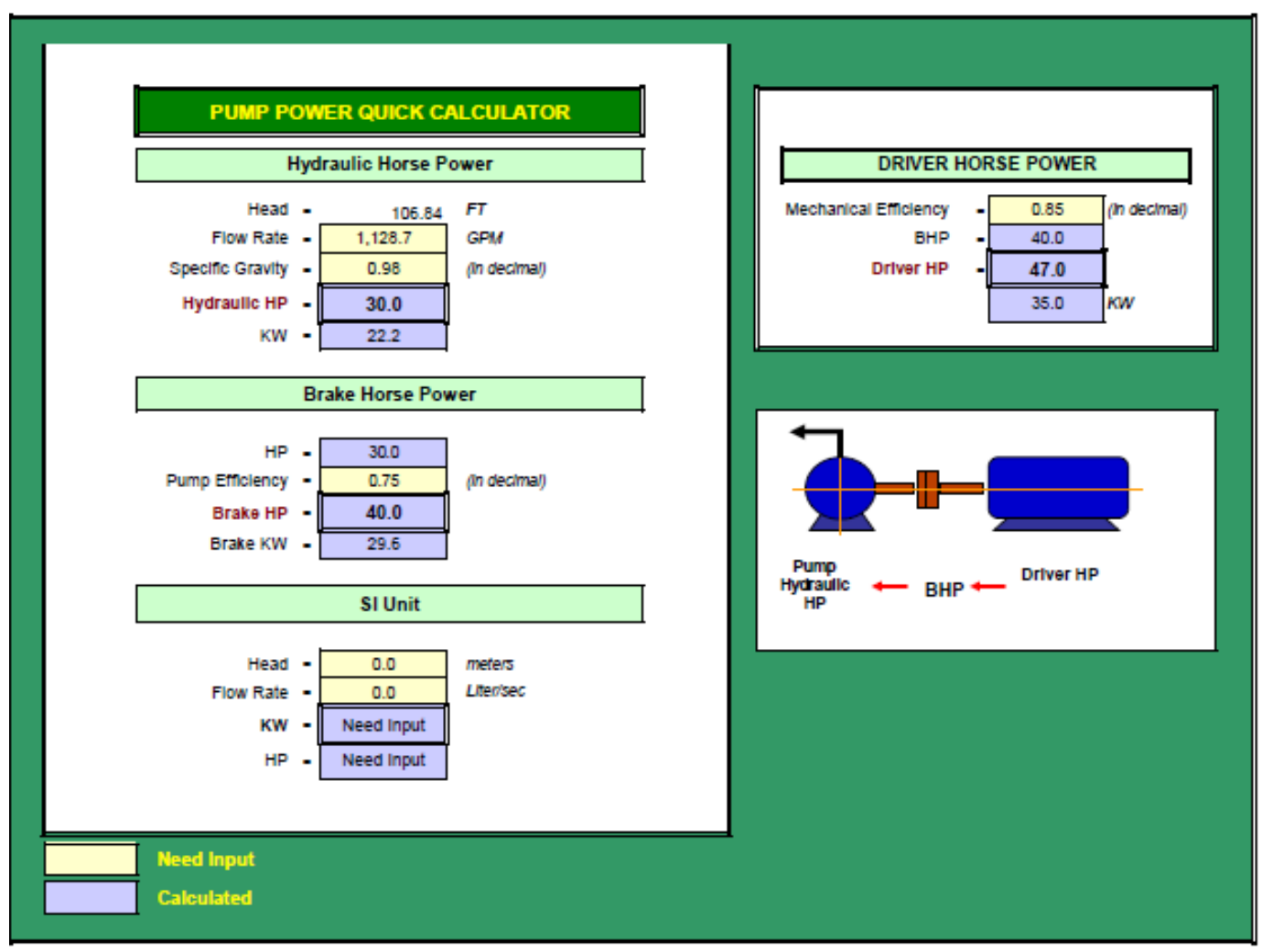

Figure 5. Calculation of pump power 
In the calculation results of the calculations, the amount of pump power required to drain the cooling fluid in the primary system is $35 \mathrm{~kW}$ or $47 \mathrm{HP}$. This amount of power should be fulfilled by two existing available pumps. Therefore, it is necessary to review the existing pump data, which is usually indicated in the specification document, as well as the data sheet, and also the pump performance chart when the pump is received from the pump vendor. Since this pump has been used for 18 years, the performance has decreased, therefore it is necessary to re-examine the performance of the pump to see the pump's capability if it is used for the primary cooling of the Bandung TRIGA reactor conversion

\section{CONCLUSION}

The analyzing of the calculation of pump power using several data assumptions has been done. The power of pump provided to drain the cooling fluid on the primary cooling system with new pipe routing as above, is $35 \mathrm{~kW}$ or $47 \mathrm{HP}$. This amount of pumping power should be fulfilled by 2 (two) existing pumps. Therefore, it is necessary to recalculate the performance of the two existing pumps, more accurately, to be able to determine the ability of the existing pumps to meet the head requirements and the cooling fluid flow rate in the primary cooling system of the Bandung TRIGA reactor conversion.

\section{REFERENCES}

1. Henky P. Rahardjo, V. Indriati Sri Wardhani. The Critical Point of Reactor TRIGA 2000 Bandung to TRIGA Reactor Fuel Plates. The $15^{\text {th }}$ Seminar sains and nuclear technology Batan-Bandung. 2015: 137-142.

2. Reinaldy Nazar, Sudjatmi Kustituantini Alfa, Ketut Kamajaya, Rian Fitriana. Rancangan Tanki Tunda Reaktor TRIGA Pelat Bandung. Jurnal Sains dan Teknologi Nuklir Indonesia. 2018; 19: 91-108.

3. K. Kamajaya. Desain Dasar Proses Konversi Reaktor Riset Bandung R.143/ RN $0102 /$ SNT 3. Pusat Sains dan Teknologi Nuklir Batan. 2018: 1-15.

4. Prachi N. Tanbe, K.K. Dhande, N.I. Jamadar. Flexibility and Stress Analysis of Piping System using CAECAR II-Case study. J. Engineering research and technology. 2014; 3: 370-374.

5. HP. Rahardjo. Piping Flexibility Analysis of The Primary Cooling System of TRIGA 2000 Bandung Reactor Due to Earkquake. Atom Indonesia, 2011; 37: 83-89.

6. V. Indriati Sri Wardhani, Henky P. Rahardjo. Pengaruh Bentuk Routing Perpipaan Sistem Pendingin Primer Reaktor TRIGA Konversi Terhadap penurunan Aktivitas N-16 di Permukaan Tanki Reaktor. Tri Dasa Mega, 2016; 18: 145-154.

7. V. Indriati Sri Wardhani, Henky P.R., K. Kamajaya, Sudjatmi K. Alfa, Reinaldy Nazar. Prediksi Penggunaan Pompa Existing untuk Pendingin Primer Reaktor TRIGA Pelat. Seminar Nasional Sains Dan Teknologi Nuklir Batan Bandung, 2017: 210-214.

8. Anonymous. Technical Reference Manual CAESAR II version, 1996: 5-24.

9. Suharto. Pompa Sentrifugal Standarisasi, Teori, Pemilihan, Pembelian, Pengoperasian, Maintenance, dan Troubleshooting, Ray Press 2016; 33-81.

10. Korakianitis, Theodosios, Rezaienia, Mohammad A., Paul, Gordon M., Rehidch, Akbar, Rothman, Martin T., Mozafari, Sahand. Optimization of Centrifugal Pump Characteristic Dimension for mechanical Circulatory Supprt Devices. Journal ASAIO. 2016; 62(5): 545-551. 